5. Larsen-Freeman D., Cameron L. Complex Systems and Applied Linguistics. Oxford, University Press, 2009. P. 229-233.

6. Keegan. D. Foundations of Distance Education. $\left(3^{\text {rd }}\right.$ ed). London: Routledge, 1996. P. 21.

7. Kerr. B. (2007d, February 3). MSG.7, Re: What Connectivism Is. Online Connectivism Conference: University of Manitoba. URL: http://ltc.umanitoba.ca/moodle/mod/forum/discuss.php?d=12

8. Arshad, K.; Imran, M. A. Increasing the Interaction Time in a Lecture by Integrating Flipped Classroom and just-in-time Teaching Concepts. June 2013. Compass Journal of Learning and Teaching 4 (7): 1-18. DOI: 10.21100/compass.v4i7.84. URL: https://journals.gre.ac.uk/index.php/ compass/article/view/84

9. Клепко С. Ф. Інтеграція і поліморфізм знання у вищій освіті. С. Ф. Клепко // Філософія освіти. 2005. № 2. С. 20-32.

10. Tomasello M. Constructing a Language: A Usage-based Theory of Language Acquisition. Cambridge, MA: Harvard University Press, 2003. P. 388.

11. Chomsky N. The Minimalist Program. (Current Studies in Linguistics 28.) Cambridge, MA: MIT Press, 1995. P. 213-226.

12. Diessel H. Linguistic Nativism. 2015. URL: http://www.personal.unijena.de/ x4diho/LA_Linguistic_nativism.pdf

DOI https://doi.org/10.30525/978-9934-26-073-5-2-67

\title{
PEER ASSESSMENT AS AN INSTRUCTIONAL METHOD IN ACADEMIC WRITING
}

\author{
Kalynovska I. M. \\ Candidate of Philological Sciences, Associate Professor, \\ Conversational English Department \\ Lesya Ukrainka Volyn National University \\ Koliada E. K. \\ Candidate of Philological Sciences, Full Professor, \\ Conversational English Department \\ Lesya Ukrainka Volyn National University \\ Lutsk, Ukraine
}

Academic writing testifies an intensive interest in peer assessment. This is due to changing conceptions of teaching and learning. In this context, peer 
assessment can be understood as «a natural extension of the move from a teacher-centred to a student-centred mode of education, which emphasises the active engagement of students in their learning, learner responsibility, metacognitive skills and a dialogical, collaborative model of teaching and learning» [5].

Within the sphere of higher education, peer assessment is frequently used as an instructional method. It is referred to as «participative assessment», i.e. «the process in which students and tutors share, to some degree, the responsibility for making evaluations and judgements about students' written work» [6]. In view of the foregoing, it should be noted that the study of peer assessment, is vital and perspective, because «the capacity to provide quality feedback is a fundamental graduate skill and should receive much greater attention in the higher education curriculum» [4]. It is important to analyse different types of peer assessment, as well as the advantages of its usage in academic writing.

To start with, there are different types of peer assessment, such as grading a peer's research report, providing qualitative feedback on a groupmate's presentation, or evaluating a fellow trainee's professional task performance [7]. Peer assessment involves students providing feedback to other students on the quality of their work. For example, written assignments could be first marked or commented on by fellow students and then the mark discussed in pairs or small groups followed by a wider discussion. Other types of peer feedback are connected with the assessment criteria. For instance, students provide comments on the work of other students, using a set of agreed criteria. They may also grade the work of other students with grades moderated by the lecturer. Some forms of peer assessment could minimise the involvement of the lecturer in the process of evaluation.

The feedback provided by students could be formative or summative [6], and it is very important to discuss evaluation points with students. Summative assessment is challenging with students who may not feel comfortable marking the work of their peers. In this case, the peer assessment could be carried out anonymously - both assessor and assessee could be anonymous [3] to reduce student discomfort. It can also be repeated multiple times during the module or course, so as to develop student experience and to build in an element of inter-subjectivity, which makes the marking more objective [3].

The main advantage of using peer assessment in academic writing is students' collaboration and knowledge exchange. Peer feedback can encourage collaborative learning through interchange of what constitutes good work [1]. Students can help each other to make sense of the gaps in their learning and understanding processes. 
Another advantage of peer assessment is the development of students' learning, writing skills, and creativity. Students engaged in grading the work of other students can heighten their own capacity for judgment and making intellectual choices [1]. They can get a wider range of ideas about their written assignments to promote self-development and self-improvement. In that way, «students learn how to learn and get into the habit of thinking about their thinking» [2].

Another advantage can be connected with democracy in the process of evaluation, i.e. «peer assessment helps to lessen the power imbalance between teachers and students and can enhance the students' status in the learning process» [1]. The focus of peer feedback can be on the process, encouraging students to clarify, review and edit their own ideas.

Peer assessment in academic writing could help students learn how to receive and give feedback which is an important part of the most work contexts, and will help them in their future career. In other words, peer assessment can be an important part of their learning process promoting the values and standards of a «community of practice» [6]. «Learning involves active participation in a 'community of practice' in which members of the community determine and structure their own practices, and construct identities in relation to these communities» [6].

All in all, peer assessment in academic writing requires students to receive and to provide either feedback or grades (or both) to their peers on the writing. Students contribute to assessment, collaborating with each other or with lecturers in assessing their own or others' writing. Participating in assessment helps students to develop greater understanding of the assessment process itself, and also the kinds of writing that are evaluated within academic writing. The advantages of using peer assessment testify students' constant engagement in learning process, and its importance for their professional lives.

\section{References:}

1. Boud, D., and N. Falchikov. Rethinking Assessment in Higher Education. London: Routledge, 2007. 224 p.

2. De Backer, L., H. van Keer, and M. Valcke. Exploring the potential impact of reciprocal peer tutoring on higher education students' metacognitive knowledge and regulation. Instructional Science, 2012. 40: 559-558.

3. Li, L., X. Liu, and A. L. Steckelberg. Assessor or assessee: How student learning improves by giving and receiving peer feedback. British Journal of Educational Technology, 2010. 41(3): 525-536.

4. Nicol, D., A. Thomson, and C. Breslin. Rethinking feedback practices in higher education: a peer review perspective. Assessment and Evaluation in Higher Education, 2014. 39: 1, 102-122. 
5. Spiller, D. Assessment Matters: Self-assessment and peer assessment. Teaching Development Unit. 2012. URL: https://kennslumidstod.hi.is/wpcontent/uploads/2016/03/assessment-matters-self-assessment-and-peerassessment.pdf (accessed 16.04.2021).

6. Teaching Academic Writing / Coffin C., Curry M. J., and others. London: Routledge, 2003. 175 p.

7. van Zundert, M., D. Sluijsmans, and J. van Merriënboer. Effective peer assessment process: research findings and future directions. Learning and Instruction, 2010. 20: 270-27.

DOI https://doi.org/10.30525/978-9934-26-073-5-2-68

\title{
THE DIFFICULTIES OF ONLINE TEACHING UNDER CONDITIONS OF DISTANCE LEARNING (BASED UPON THE EXPERIENCE OF TEACHING PROFESSION-ORIENTED ENGLISH)
}

\author{
Kyrykylytsia V. V. \\ Candidate of Pedagogical Sciences, Associate Professor, \\ Associate Professor at the Foreign Languages Department for Natural \\ Sciences and Mathematics \\ Lesya Ukrainka Volyn National University
}

Onyshchenko I. A.

Senior Lecturer at the Foreign Languages Department for Natural Sciences and Mathematics Lesya Ukrainka Volyn National University

Yatsyniak O. P. Assistant Lecturer at the Foreign Languages Department for Natural Sciences and Mathematics Lesya Ukrainka Volyn National University Lutsk, Ukraine

Online teaching and learning have become increasingly popular since the quarantine period connected with the coronavirus pandemic started throughout the world. A sudden outbreak of COVID-19 has destabilized the entire educational system worldwide, forcing the educators to shift from the classroom to online mode during the pandemic period, which requires a 